YEARBOOK

of ANTITRUST

and REGULATORY

STUDIES

www.yars.wz.uw.edu.pl
Peer-reviewed scientific periodical, focusing on legal and economic issues of antitrust and regulation. Creative Commons Attribution-No Derivative Works 3.0 Poland License.

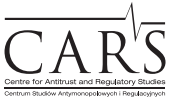

Centre for Antitrust and Regulatory Studies, University of Warsaw, Faculty of Management www.cars.wZ.uw.edu.pl

\title{
Effect of National Decisions on Actions for Competition Damages in the CEE Countries
}

\author{
by \\ Evelin Pärn-Lee*
}

\section{CONTENTS}

I. Introduction

II. Discussion on the main implementation challenges of Article 9 of the Damages Directive

1. Introductory remarks

2. Binding effect of the findings of final national decisions

3. National decisions on an infringement of competition law as prima facie evidence

III. Comparison of CEE countries

1. Introductory remarks

2. Article 9(1) of the Damages Directive

3. Article 9(2) of the Damages Directive

IV. Conclusion

\section{Abstract}

One of the main objectives of the so-called Damages Directive (2014/104/EU) was to make antitrust enforcement more effective. Although in most EU countries private antitrust enforcement has been possible subject to general rules of civil law; the number of private antitrust litigations has remained relatively low. It is presumed that the complementary roles of public and private enforcement, as well as the synergy between them, will take effect if formal decisions taken during public enforcement will have binding effect with regard to follow-on private litigations. According to the Damages Directive, final national decisions on competition infringements shall have binding effect in follow-on litigations. What

* Evelin Pärn-Lee - Junior researcher and a PhD student at Tallinn Technical University, lecturer at Tallinn Technical University and Tartu University, attorney-at-law; evelinparnlee@gmail.com. Article received: 12.06.2017; accepted: 21.08.2017. 
is to be understood under 'binding effect', and the potential effects thereof, has been subject to a lively debate among academics and practitioners. It has been questioned if decisions of an executive body can bind the judiciary, and if so, to what extent. What is the evidentiary value of a formal decision of a NCA regarding national courts, but also on the court of another Member State. The article deals with the main issues and arguments presented in the general debate on the binding effect of national competition law decisions, and provides a closer look on this topic with regard to specific CEE countries.

\section{Résumé}

L'un des objectifs principaux de soi-disant Directive Dommages (2014/104/UE) était de rendre l'application privée du droit de la concurrence plus efficace. Bien que, dans la plupart des pays de l'UE, l'application privée du droit de la concurrence a été possible à la base des règles générales du droit civil; le nombre de litiges privés portant sur les violations du droit de la concurrence est resté relativement faible. Il est présumé que les rôles complémentaires de l'application publique et privée du droit de la concurrence, ainsi que la synergie entre eux, prendront effet si les décisions formelles prises lors de l'application publique du droit de la concurrence auront un effet contraignant en ce qui concerne les litiges privés subséquents. Conformément à la Directive Dommages, les décisions nationales définitives concernant les infractions en matière de concurrence ont un effet contraignant dans les procédures civiles ultérieures. Ce qui doit être compris sous «effet contraignant», et ses effets potentiels, a fait l'objet d'un débat animé entre les universitaires et les praticiens. On s'est demandé si les décisions d'un organe exécutif peuvent avoir un effet contraignant sur le pouvoir judiciaire et, si oui, dans quelle mesure. Quelle est la valeur probante d'une décision formelle d'une ANC concernant les tribunaux nationaux, mais aussi le tribunal d'un autre État membre. Larticle analyse des principaux problèmes et arguments présentés dans le débat général sur l'effet contraignant des décisions nationales portant sur le droit de la concurrence, et examine de plus près ce sujet en ce qui concerne certains pays d'Europe centrale et orientale.

Key words: private antitrust enforcement; damages directive; effect of national decisions on actions for competition damages; litigations; binding effect of national decisions; irrefutability; prima facie evidence; presumptions; implementation; legal certainty; effectiveness.

JEL: K13; K15; K21; K41 


\section{Introduction}

The right to claim damages for harm caused through anticompetitive conduct was confirmed by the Court of Justice of the European Union (CJEU) in Courage and Crehan ${ }^{1}$ already in 2001, and subsequently confirmed in several later rulings. ${ }^{2}$ Nevertheless, the system of private antitrust enforcement in the EU is considered inefficient, ${ }^{3}$ with a relatively low number of legal actions when compared with the United States (MacGregor and Boyle, 2014). More than half of the EU Member States have reported ${ }^{4}$ a full transposition of Directive 2014/104/EU. 5

The Damages Directive intends to remove the biggest impediments for potential legal actions and to promote the submission of damages claims in private litigation. In addition to essential procedural issues such as standing, collective redress and disclosure of evidence, the Damages Directive also provides for the binding effect of final decisions issued by National Competition Authorities (hereinafter, NCAs) and their review courts. This solution is intended to remove from the claimants the need to prove the competition infringement, and thus reduce the cost of litigation and increase the probability of successful follow-on case (Peyer, 2016). Regardless of the efforts made at EU level, encouraging private antitrust enforcement across the EU needs substantial law standardisation and the adjustment of procedural differences. Only when there are no major legal differences for the claimant with regard to the forum, thus no incentive to consider forum shopping, would equal legal certainty as to the right to claim compensation across the EU is guaranteed, at least in theory.

\footnotetext{
1 Judgment of 20.09.2001, Courage and Crehan, case C-453/99, ECLI:EU:C:2001:465.

2 See for example judgment of 13.06.2006, Manfredi, joined cases C-295/04 to C-298/04, ECLI:EU:C:2006:461, judgment of 14.06.2011, Pfleiderer, case C-360/09, ECLI:EU:C:2011:389, judgment of 06.06.2913, Donau Chemie, case C-536/11, ECLI:EU:C:2013:366, judgment of 05.06.2014, Kone AG, Otis GmbH, Schindler Aufzüge und Fahrtreppen GmbH, Schindler Liegenschaftsverwaltung GmbH, Thyssen Krupp Aufzüge GmbH v. ÖBB-Infrastruktur AG, case C-557/12, ECLI:EU:C:2014:1317.

3 As stated e.g. in European Commission, White paper on damages actions for breach of the EC antitrust rules, COM/2008/0165 final. Retrieved from: http://ec.europa.eu/competition/ antitrust/actionsdamages/files_white_paper/whitepaper_en.pdf (07.06.2017).

${ }^{4}$ Including Estonia, Lithuania, Slovakia and Slovenia. See: http://ec.europa.eu/competition/ antitrust/actionsdamages/directive_en.html.

5 Directive 2014/104/EU of the European Parliament and of the Council of 26.11.2014 on certain rules governing actions for damages under national law for infringements of the competition law provisions of the Member States and of the European Union, OJ L 349, 05.12.2014. In the article referred to also as the Damages Directive.
} 
The synergy that the cooperation of private and public litigation of antitrust violations creates benefits first and foremost those who have suffered harm due to an anticompetitive behaviour. Considering the complexities of private antitrust enforcement issues, binding effect of formal national decisions should, at least in theory, eliminate some uncertainty and reduce the cost of litigation for claimants. Even though the litigation outcome of private antitrust enforcement cannot be predicted, it should facilitate decision-making on the where and when, as well as whether to litigate at all.

This article will analyse the effect of national decisions on actions for damages caused by competition law infringements in Central and Eastern European (hereinafter, CEE) countries. ${ }^{6}$ The article is divided into four sections. Section one contains this introduction; section two provides the general discussion on this topic; a comparative view of CEE countries is presented in section three, as reported by relevant national rapporteurs (Piszcz, 2017); section four contains concluding remarks.

\section{Discussion on the main implementation challenges of Article 9 of the Damages Directive}

\section{Introductory remarks}

According to Article 9(1) of the Damages Directive, Member States are requested to 'ensure that an infringement of competition law found by a final decision of a national competition authority or by a review court is deemed to be irrefutably established for the purposes of an action for damages brought before their national courts under Article 101 or 102 of TFEU or under national competition law'. As provided in recital 34 of the Preamble of the Damages Directive, the aim is to avoid re-litigation of decisions that have become final. In addition, Article 9(2) of the Damages Directive proposes to the Member States to "ensure that where final decision on infringement of competition law is taken in another Member State, that final decision may, in accordance with national law, be presented before their national courts as at least prima facie evidence that an infringement of competition law has occurred'. Pursuant to recital 35 of the Preamble of the Damages Directive, it should be possible to present the findings of an infringement of Article 101 or 102 TFEU contained in a final decision of a NCA or review court originating

${ }^{6}$ Bulgaria, Croatia, Czech Republic, Estonia, Latvia, Lithuania, Poland, Romania, Slovakia and Slovenia. 
from another Member State as prima facie evidence on the fact that an infringement of competition law has occurred.

In general, the binding effect of final national decisions serves two main purposes: first, to ensure efficiency and consistency of public and private enforcement of EU competition law and, second, to relieve the plaintiffs from the burden to prove the infringement of competition law (Nazzini, 2015). However, the binding effect of final national decisions on competition law infringements in follow-on civil proceedings, as set out in Article 9 of the Damages Directive, seems to be one of its most controversial provisions (Frese, 2015). As provided by different commentators (see for example Nazzini, 2015; Merola and Armati, 2016; Panzani, 2015), it is not entirely clear if the decision of an executive body, such as a NCA, can bind national courts. Therefore also, it is uncertain if a distinction should be made between a NCA decision and a decision of its review court. Moreover, what is the scope of the 'binding effect' of final infringement decisions, and does it only bind the addressee of the final decision, or does it have wider effect and thus affect any person mentioned in the relevant finding(s)? Or, what are the evidentiary value of a final national decision and its findings of a competition law infringement in stand-alone proceedings?

\section{Binding effect of the findings of final national decisions}

Some commentators have questioned if the legal act of a NCA, which is an executive body, can be binding on the judiciary (Panziani, 2015) and, as such, if the rules of Article 9(1) do not violate the separation of powers principle and possibly also the rules on the protection of fundamental rights codified in the European Convention of Human Rights and Fundamental Freedoms ${ }^{7}$ and the Charter of Fundamental Rights of the European Union. ${ }^{8}$ Italy has been most critical of these issues as in the Italian legal order the decisions of their NCA represent, at best, prima facie evidence (Grassani, 2013; Panzani, 2015; Merola and Amati, 2016). In the United States, where private enforcement of antitrust violations is well established, the findings of an antitrust infringement established by their competition authorities is also not binding on the judiciary, and represents only prima facie evidence ${ }^{9}$ rebuttable in litigation (Foer and Cuneo, 2012). Germany, on the other hand, had established the binding effect of the findings of a competition law infringement in follow-on litigation as

\footnotetext{
7 For example Art. 6 prescribing the right to a fair trial.

${ }^{8}$ For example Art. 47 prescribing the right to an effective remedy and to a fair trial.

9 Section 2 sub-clause b of US Clayton Act. Retrieved from: http://gwclc.com/Library/ America/USA/The\%20Clayton\%20Act.pdf (07.06.2017).
} 
law. According to sub-section 33(4) of the Competition Act (Gesetz gegen Wettbewerbsbeschränkungen ${ }^{10}$ ), a national court is bound by the findings on an infringement of competition law established by the European Commission or a NCA or its reviewing court of any Member State. The rule that the court cannot deviate from the final decision of a NCA exists also in the UK (Sections 18 and 20 of the UK Enterprise Act 2002, which are inserted as Section 58A into the UK Competition Act 1998). As referred to in Section 3 of this article, most of the CEE counties have generally followed the same model, except Bulgaria where the decisions of NCA have no direct binding effect (see also Piszcz, 2017).

Commission decisions are binding upon national courts, subject to principles provided in the case law of EU courts, ${ }^{11}$ but also in primary ${ }^{12}$ and secondary ${ }^{13}$ EU legislation. Taking also into account the cooperation obligation of the Commission and NCAs, ${ }^{14}$ the binding character of national decisions in follow-on litigations, as provided in Article 9(1) of the Damages Directive, is not only an essential but an appropriate consequence (see also Komninos, 2007). With respect to the protection of fundamental rights therefore, as provided by Frese with reference to the CJEU case European Community v. Otis and Others ${ }^{15}$ the protection of fundamental rights applies also to private antitrust enforcement (Frese, 2015), hence the Member States must ensure them. ${ }^{16}$

10 Retrieved from: https://www.bgbl.de/xaver/bgbl/start.xav?startbk=Bundesanzeiger_ BGBl\&jumpTo=bgbl113s1750.pdf\#_bgbl_\%2F\%2F*\%5B\%40attr_id\%3D \%27bgbl113s 1750 . pdf\%27\%5D_1496842507450 (07.06.2017).

11 See for example judgment of 28.02.1991, Delimits v. Henninger Bräu, case C-234/89, ECLI:EU:C:1991:91 or judgment of 14.12.2000, Masterfoods Ltd v. HB Ice Cream Ltd, case C-344/98, ECLI:EU:C:2000:689. In judgment of 06.11.2012, European Community v. Otis, case C-199/11, ECLI:EU:C:2012:684, CJEU stated in para 46 that 'Commission decisions (...) are binding on national courts'.

12 See to that effect Art. 288 TFEU and Art. 4(3) of TEU.

13 According to Art. 16 of Council Regulation (EC) No. 1/2003 of 16.12.2002 on the implementation of the rules on competition laid down in Articles 81 and 82 of the Treaty (hereinafter, Regulation 1/2003) 'when national courts rule (...) which are already subject of a Commission decision, they cannot take decisions running counter to the decision adopted by the Commission'. This rule codifies the principle ruled by judgment of 14.12.2000, Masterfoods Ltd v. HB Ice Cream Ltd, case C-344/98, ECLI:EU:C:2000:689 (called also the Masterfoods doctrine) pursuant to which national courts must avoid giving decisions which would conflict with a decision contemplated by the Commission (para 51). If a national court rules on a conduct that is already decided with a Commission decision, then the decision of the national court cannot run counter that earlier Commission decision (para 52). Such binding effect of the decisions of the Commission is of course without prejudice to the interpretation of Community law by CJEU.

14 As provided in Art. 11 Regulation 1/2003

15 Judgment of 06.11.2012, European Community v. Otis, case C-199/11, ECLI:EU:C:2012:684.

16 For CJEU the binding effect rule does not limit the defendants right to tribunal as per Article 47 of the Charter of Fundamental Rights of the European Union, as, first, the 
The Commission has repelled accusations on lessening judicial protection and potential problems with securing fundamental rights by pointing to the fact that any final NCA decision is still subject to national judicial review. ${ }^{17}$ Hence, it is not that an administrative authority has the final word when interpreting national competition law. With regard to EU competition law, the ultimate say on its interpretation is limited by Article 9(3) of the Damages Directive that prescribes that the binding effect requirement is 'without prejudice to the rights and obligations (...) under Article 267 TFEU'. Some commentators (such as Frese, 2015) fear that this will further incentivise a surge of new litigations on national NCA decisions. However, others consider this to be unlikely, because the binding effect of NCAs' decisions, or their acceptance as prima facie evidence, has, in fact, been part of the legislation of some Member States for a long time already (Peyer, 2016).

As provided in Article 9(1) of the Damages Directive 'an infringement of competition law found by a final decision (...) is deemed to be irrefutably established'. Recital 34 of the Preamble clarifies this by stating that the finding of an infringement of Article 101 or 102 TFEU in a final national decision should not be re-litigated. It also states that the effect of the finding should cover only (i) the nature of the infringement and its (ii) material, (iii) personal, (vi) temporal and (v) territorial scope. This indicates that the irrefutability refers rather to the evidential findings (iuris et de iure) of the antitrust infringement and not to the resolution, applying a narrow interpretation, or to the entire decision, applying a wide interpretation. However, it is not entirely clear what is the consequence of findings that establish an infringement of competition law, such as the nature of the infringement, but fail to establish its temporal and personal scope. In such a case, it is very likely that in a follow-on action the claimant still bears the burden of proof concerning those aspects which are not clearly stated in the findings. Or, if the claimant disagrees with some of the findings established in the final national decision, is the claimant then bound by these findings in a follow-on action or does the claimant have the right to go cherry picking and apply irrefutability with regard to some aspects, for example the nature of the infringement and its material scope,

Commission decision is subject to review by EU courts under Article 263 TFEU (judgment of 06.11.2012, European Community v. Otis, case C-199/11, ECLI:EU:C:2012:684, para 57), second, the defendants in fact brought actions for annulment of the Commission decisions (Case C-199/11, para 57), third, the review by EU courts is both on the law as well as on the facts, meaning that evidence is also assessed (case C-199/11, para 63).

17 European Commission, Proposal for a Directive of the European Parliament and of the Council on certain rules governing actions for damages under national law for infringements of the competition law provisions of the Member States and of the European Union, COM (2013) 404 final. Retrieved from: http://ec.europa.eu/transparency/regdoc/rep/1/2013/EN/1-2013-404EN-F1-1.Pdf (07.06.2017). 
but waive irrefutability and choose to re-litigate the personal, temporal and territorial scope of the infringement. As there is hardly any national court practice on the matter, these issues cannot be answered with certainty.

\section{National decisions on an infringement of competition law as prima facie evidence}

The issue of providing binding effect to final decisions originating from other EU Member States was controversial as well. As a response to numerous critical comments submitted by Member States' authorities ${ }^{18}$ and diversified commentators (for example Panzani, 2015; Nazzini, 2015; Merola and Armati, 2016), the effect of such cross-border final decisions is limited to prima facie evidence only (Frese, 2015). Although this choice has been regarded by some commentators as most appropriate, considering the lack of formal and substantive harmonisation of applicable rules and procedures within the NCAs across the EU, such compromise does raise its own issues. To start with, the approach chosen seems to follow an earlier standpoint of the Commission expressed in the proposal for Regulation 1/2003 that 'decisions adopted by NCA do not have legal effects outside the territory of their Member State, nor do they bind the Commission'. ${ }^{19}$ In general, NCAs have no jurisdiction outside their own territories, neither to investigate nor to take such decisions. Even though Regulation 1/2003 has brought about a substantial level of convergence in antitrust enforcement, divergences still exists. ${ }^{20}$

The Damages Directive does not specify how the term prima facie evidence is to be furnished. The concept of prima facie is linked to the legal burden of the parties. ${ }^{21}$ In general, the burden of proof determines at first which party must provide the facts and the relevant evidence (evidential burden). The

18 See for that purposes comments made to the White Paper on Damages actions for breach of the EC antitrust rules available at http://ec.europa.eu/competition/antitrust/actionsdamages/ white_paper_comments.html (07.06.2017).

${ }_{19}$ The territorial scope is not entirely clear from the wording of Art. 5 of Regulation 1/2003. However, in the Proposal for a Council Regulation on the implementation of the rules on competition laid down in Articles 81 and 82 of the Treaty and amending Regulations (EEC) No. 1017/68, (EEC) No. 2988/74, (EEC) No. 4056/86 and (EEC) No. 3975/87, COM(2000) 582 final the Commission is rather clear on this issue (see comments on Art. 5).

${ }^{20}$ As provided by the Commission Communication Ten Years of Antitrust Enforcement under Regulation 1/2003: Achievements and Future Perspectives. COM(2014) 453. Retrieved from: http://ec.europa.eu/competition/antitrust/legislation/regulations.html (07.06.2017). According to the Commission, there are two main aspects of differences: (i) institutional position of NCAs, i.e. whether they can execute the duties in an impartial and independent manner, and (ii) national procedures and sanctions.

${ }^{21}$ Based on the principle of ei incumbit probatio qui dicit, non qui negat, i.e. the burden of proof is on the one who declares, not on one who denies. 
allocation of that burden determines which of the parties to the dispute bears the risk of facts remaining unresolved or allegations unproven (legal or material burden). ${ }^{22}$ The rules on the burden of proof are provided in every national legal system in the EU. However, one must take into consideration that the concept and terminology of prima facie evidence has its roots in common law, which also distinguishes between a legal burden ${ }^{23}$ and an evidential burden ${ }^{24}$ (Nazzini, 2015). According to Nazzini, EU courts systematically apply the concept of a prima facie case; however, they very rarely distinguish between a legal and an evidential burden in a consistent way. ${ }^{25}$ Therefore, for Nazzini, prima facie evidence is evidence that, 'if contradicted and unexplained, can be accepted by the tribunal of fact as proof'. A final decision on an infringement of competition law presented to a court of another Member State is admissible as evidence which enables, but does not obligate, the court to find that the infringement prescribed in the decision is proven (Nazzini, 2015). For Merola and Armati, the prima facie evidence of Article 9(2) seems to fall within the category of iuris tantum (that is, simple evidence), which is rebuttable with evidence with the same level of probative value (Merola and Armati, 2016). Even though in cross-border cases the final decision of a NCA of another Member State has probative value, it is still up to the judge to decide in a follow-on case how much weight the judge will assign to a final decision on an infringement of competition law originating from another Member State. It may be that a judge deciding on a follow-on action wants to ensure that procedural standards applied in the other Member State comply with those of the deciding Member State. Therefore, it may happen that a judge affords less weight to a NCA decision from another Member State than that of prima facie evidence if the procedural standards in the other Member State are lower than that of the deciding Member State, or orders a full reinvestigation of the facts (Wright, 2016). Can a judge refuse to consider a final decision on a competition law infringement originating from another Member State as prima facie evidence? Probably yes, if this is objectively justified. Additionally, one has to pay attention to the Brussels Regulation 1215/2012, ${ }^{26}$ which

22 See for example reference 60 of AG Kokott Opinion in case C-8/08 T-Mobile Netherlands $B V v$. Raad van bestuur van de Nederlandse Mededingingsautoriteit.

${ }^{23}$ Legal burden indicates, for example, that someone is presumed innocent unless proven otherwise. Legal burden never shifts but can be allocated by the parties.

${ }^{24}$ Evidentiary burden is flexible in nature, indicating that the party making a claim must provide proof thereof. Evidentiary burden can be acquired by the defendant and shift back to the claimant.

25 Except in case C-105/04 P Nederlandse Federative Vereninging voor de Groothandel op Elektrotechnisch Gebied v. Commission. See also the opinion of AG Kokott in the same case.

${ }^{26}$ Regulation (EU) No. 1215/2012 of the European Parliament and of the Council of 12.12.2012 on jurisdiction and the recognition and enforcement of judgments in civil and 
provides in its Article 45 rules for recognising and enforcing judgments, and which makes it possible to refuse to recognize a judgment if such recognition would be manifestly contrary to public policy (order public) or if the judgment was given in default.

The above provides that final decisions on competition law infringements taken in another Member States may be presented to national courts dealing with a damages case, but as the rules on the standard of proof are governed by national law, it is up to the judge to decide, subject to national procedural law, if and to what extent to accept them; provided of course, that the EU principles of equivalence and effectiveness are applied. It should, however, be easier to make a valid damages case if one does not have to start the case with proving the anticompetitive activity itself. Therefore, prima facie reduces the amount of resources that the plaintiff must use. They, however, still carry the burden of proving harm suffered as well as the causal link between the harm and the relevant infringement.

\section{Comparison of CEE countries}

\section{Introductory remarks}

The subsequent comparison of how the provisions on the effect of national decisions have been implemented into national legislation refers to the following $11 \mathrm{EU}$ Member States (named also Central and Eastern European countries): Bulgaria, Croatia, Czech Republic, Estonia, Hungary, Latvia, Lithuania, Poland, Romania, Slovakia and Slovenia.

\section{Article 9(1) of the Damages Directive}

In Bulgaria, the transposition of Article 9(1) of the Damages Directive is somewhat complicated. The Bulgarian Constitutional Court ruled already in 1998 that legal provisions set out in Article 36 of the Protection of Competition Act, ${ }^{27}$ according to which decisions of the Bulgarian NCA are

\footnotetext{
commercial matters, OJ L 351/9, 20.12.2012.

27 Protection of Competition Act (Закон за защита на конкуренцията), promulgated in State Gazette no. 102 of 28.11.2008, in force as of 02.12.2008. This is the third version of the act, which was drafted with the assistance of the Italian competition authority (Autorità garante della concorrenza e del mercato) and EU financial support under the PHARE programme. Bulgaria introduced competition legislation in 1991 with the adoption of the first PCA (promulgated in
} 
binding on civil courts, contradict, in fact the constitutional principles of the rule of law, ${ }^{28}$ separation of powers ${ }^{29}$ and judicial independence ${ }^{30}$ In general, only those decisions of the Bulgarian NCA that have been reviewed by the Supreme Administrative Court and upheld by the latter can have binding effect on domestic civil courts. ${ }^{31}$ Civil courts cannot re-analyse the substantive legality of a NCA decision that has already been confirmed by the Supreme Administrative Court. On the other hand, a civil court will neither establish an infringement nor award damages in a follow-on litigation which is based on a NCA decision that has been overruled by the Supreme Administrative Court. It is also reported that binding effect is limited in Bulgaria only to the persons that were parties to the initial NCA litigation (see for that Petrov, 2017). Thus, it is to be expected that the Bulgarian legal system will not be able to implement the concept of the binding effect in full.

In Croatia, however, the drafters of the act implementing the Damages Directive into their legal system see no problems with harmonising the concept of binding effect of domestic infringement findings in follow-on actions in full. It has been reported that, prior to the implementation of the Damages Directive, the courts had to take the decisions of the Croatian NCA into account, but were not bound by them (see for that Malnar, 2017).

In the Czech Republic, decisions issued by administrative authorities that establish an infringement are binding on the courts. Moreover, decisions issued by administrative authorities stating that no infringement has been committed are subject to judicial review, the consequence of which can be that the court establishes an infringement. In that respect, the legal system of the Czech Republic is considered in compliance with the rule on the binding effect set out in Article 9(1) of the Damages Directive. Even more, the legislator has chosen to prescribe clearly that the binding effect applies also to Commission decisions (see for that Petr, 2017).

\footnotetext{
State Gazette no. 39 of 17.05.1991, in force as of 20.05.1991). It was soon revised in line with modern EU competition law doctrine, which became the basis for the development of national antitrust and merger control rules, with the adoption of another PCA in 1998 (promulgated in State Gazette no. 52 of 08.05.1998, in force as of 11.05.1998). Ten years later at the end of 2008, following Bulgaria's accession to the EU on 01.01.2007, the current third instalment of the PCA came into force, which further harmonized the procedure for antitrust enforcement and merger control in line with the changes which were introduced by Regulation 1/2003 and Regulation 139/2004.

28 Art. 4 of the Bulgarian Constitution.

29 Art. 8 of the Bulgarian Constitution.

30 Art. 117(2) of the Bulgarian Constitution.

31 Art. 104 of the Bulgarian Protection of Competition Act.
} 
Estonia $^{32}$ has opted for a solution whereby the final decision of the Estonian NCA or a review court on an infringement of competition law is binding on the court that deals with the damages claim in a follow-on action. ${ }^{33}$ What makes this solution difficult to grasp is the multiplicity of procedures applicable in Estonia to competition law infringements. Infringements related to anticompetitive arrangements (Article 101 of TFEU) are considered a criminal offence, ${ }^{34}$ to which criminal procedural rules apply. Conduct related to an abuse of a dominant position (Article 102 of TFEU) is a misdemeanour, governed by the provisions on misdemeanour proceedings along with the rules of criminal procedure. Certain anticompetitive actions are processed according to the rules of administrative proceedings. The legal drafters explain the term 'binding' to mean that there is no obligation for the claimant to prove the infringement before a civil court, as this is considered proven. Yet it remains unclear if the whole judicial reasoning is binding on a civil court or merely the resolution of the decision, since no clarification with this regard is provided (see for that Pärn-Lee, 2017).

Already as of July 2014, the courts in Hungary are bound by the final decisions of the Hungarian NCA. ${ }^{35}$ The law makes no distinction if the binding effect applies only to the operative part of the decision or also to its reasoning; it is assumed to extend to both. It is provided by law that civil court decisions should not contradict the decisions of the Hungarian NCA. However, civil courts are not bound by commitment decisions of the Hungarian $\mathrm{NCA}^{36}$ (see for that Bodnar, 2017).

Current Latvian legislation does not recognise facts established in a decisions of an administrative court binding in civil court proceedings. Therefore, the decision of an administrative authority is currently not binding on civil courts. Latvian commentators have reported an abuse of a dominant position case related to Riga Free Port, where only the Supreme Court found that the

32 On 05.06.2017, the law on Amending Competition Act and other acts related thereto entered into force, implementing the Damages Directive into Estonian legal system.

33 Section $78^{12}(1)$ of the Estonian Competition Act.

${ }^{34}$ In general, Estonian criminal procedural law allows the court to handle a civil claim as part of the criminal matter. However, this possibility has now been specifically excluded with regard to damages claims arising from anticompetitive arrangements (Article 101 TFEU or corresponding national rule). The Estonian Code of Criminal Procedure (in Estonian Kriminaalmenetluse seadustik, passed on 12.02.2003, entry into force on 01.07.2004. English version available at: https://www.riigiteataja.ee/en/eli/530052017002/consolide (07.06.2017)) has been amended with Section $38^{2}$ whereby damage claims of victims of criminal offences related to competition shall be treated in civil proceedings.

35 Which is considered a unique phenomenon, as a general court is not bound by the decisions of the administrative authority.

36 There has been a case where the court established an infringement of competition law although the NCA terminated its procedure with commitments. 
decision of the Latvian NCA can be referred to $^{37}$ in civil proceedings. The draft law implementing the Damages Directive provides that infringements of competition law established in a decision of the Latvian NCA do not need to be proven by the claimant. Commentators point to some problematic limitations in the decisions of the Latvian NCA. According to tort rules, when claiming damages the plaintiff has to prove (i) the illegal action or omission, (ii) the existence of losses and, (iii) the causal link between them. It is also essential to prove the fault of the infringer, that is, that the losses are the result of illegal activities of the infringer. However, decisions of the Latvian NCA reportedly do not address the issue of fault. No legal analysis of negligence or intent is provided. Further on, the issue of harm to other market participants is not considered either. This can make follow-on actions difficult, if not impossible and, consequently, claimants still need to proceed with stand-alone cases (see for that Jerneva and Druviete, 2017).

In Lithuania, decisions of the domestic NCA that have not been subject to judicial review are currently regarded as official written evidence with a higher evidential (prima facie) value..$^{38}$ Also, the Lithuanian Supreme Court has ruled that a mere infringement decision does not establish civil liability, as for this all relevant elements must be proven. This, however, is planned to change as, according to the new amended Competition Law, final decisions of the Lithuanian NCA as well as its review courts become binding on civil courts. Further on, according to Article 51(3) of the new Competition Law, the scope of the infringement decision is established. ${ }^{39}$ Decisions of the Lithuanian NCA which indicate an infringement but fail to provide any statements or evidence are not regarded as binding. Neither are the opinions of the Lithuanian NCA addressed to the court on the issue of calculating damages (see for that Mikelenas and Zaščiurinskaitè, 2017).

Poland has opted to fully implement Article 9(1) of the Damages Directive, meaning that a final decision of the Polish NCA as well as relevant review court is considered binding in civil follow-on actions, but only with respect to the declaration on the infringement of competition law (see for that Piszcz and Wolski, 2017).

Romania is reported to be implementing the provisions of Article 9(1) almost literally, meaning that infringements established in a final decisions of the Romanian NCA as well as those delivered by any Romanian courts,

${ }^{37}$ In is not clear, however, if this means binding effect.

38 According to Art. 197(2) of the Code of Civil Procedure, circumstances of prima facie evidence are considered fully proven, provided they are not rebutted by other evidence except for witness evidence. Witness evidence can be engaged only where the principles of fairness, justice and reasonability are at stake.

39 Binding are foremost the nature of the infringement, its territory, duration and infringer. 
will establish irrefutably that a competition law infringement has taken place. In that respect, the draft law implementing the Damages Directive does not impose any limitations on courts reviewing NCA decisions, and the binding effect is extended to any court decision establishing an infringement of competition law (see for that Mircea, 2017).

In Slovakia, the courts are legally bound by the decisions of an administrative authority establishing an infringement. Hence, Slovakian law is considered in compliance with Article 9(1) of the Damages Directive (see for that Blažo, 2017).

Slovenia has reportedly been inspired by Article 16 of Regulation 1/2003; as a result, the national legal system has been in conformity with the rules set out in Article 9(1) and 9(3) of the Damages Directive already since 2008. As a matter of fact, the final decisions of administrative authorities are binding on courts. ${ }^{40}$ Thus national courts assessing follow-on damage claims are bound by the final decisions of the Slovenian NCA as well as the decisions of the Commission. Therefore, in relevant follow-on actions, the claimants only need to prove: (i) loss, (ii) defendant's fault and, (iii) that there is a causal relationship between the infringement and the loss sustained (see for that Vlahek and Podobnik, 2017).

\section{Article 9(2) of the Damages Directive}

As reported in Bulgaria, the drafters of the national legislation have chosen to disregard the concept of prima facie evidence and no special authority is granted to the final decisions originating from other Member States.

With regard to cross-border cases, Croatia has opted for a solution whereby the findings of other Member States' NCAs on infringements of EU competition law are subject to a rebuttable presumption. However, their findings on infringements of their national competition laws have no legal effect.

In cross-border action, decisions issued by NCAs of other Member States have no binding effect in the Czech Republic, although they can be presented in a legal action and are subject to a rebuttable presumption. It has also been said that national civil courts are reluctant to stay their proceedings while the Czech NCA investigates a potential infringement; Czech courts like to assess the legal matter on their own without waiting for the outcome of the investigation by the Czech NCA.

40 As set forth in the judgment of the High Court of Ljubljana of 21.11.2013, Blitz v. Kolosei. 
Estonian civil law is already in compliance with the requirement of Article 9(2) of the Damages Directive. Final decisions originating from other Member States on an infringement of competition law will be considered documentary evidence, subject to sub-section $272(1)^{41}$ or $272(2)^{42}$ of the Estonian Code of Civil Procedure, ${ }^{43}$ as any written documents (including court decisions) can be filed with the court as evidence, provided they contain information on facts relevant for the case. Estonian law requires the judges to evaluate all evidence pursuant to the law from all perspectives, thoroughly and objectively and to decide, according to the conscience of the judge, whether or not the arguments provided by the parties in the case are proven. ${ }^{44}$ Still, no evidence has predetermined weight for a court. ${ }^{45}$ It is therefore to be assumed that in cross-border cases in Estonia, final decisions originating from other Member States on infringements of competition law are iuris tantum (that is, simple evidence), which can be rebutted by the defendant with any other evidence of the same evidentiary level.

With regard to Article 9(2), Hungary has opted to accept final decisions on an infringement of competition law originating from other Member States as factual evidence.

In cross-border actions, Latvia has opted to introduce a rebuttable presumption that the infringement had occurred, thus not referring to terminology of prima facie evidence.

In Lithuania, final decisions on an infringement of competition law originating from other Member States shall have prima facie effect with regard to Article 101 and 102 TFEU.

With regard to cross-border actions, Poland decided to treat decisions rendered in other Member States less favourably than domestic ones and, as a result, no changes are planned in its legal system.

41 According to sub-section 272(1) of the Estonian Code of Civil Procedure, documentary evidence is a written document or other document or similar data medium which is recorded by way of photography, video, audio, electronic or other data recording, contains information on facts relevant to the adjudication of a matter and can be submitted in a court session in a perceptible form.

42 According to sub-section 272(2) of the Estonian Code of Civil Procedure, official and personal correspondence, decisions in other cases and opinions of persons with specific expertise submitted to the court by the participants in the proceeding are also deemed to be documents.

43 In Estonian: Tsiviilkohtumenetluse seadustik, passed on 20.04.2005, entry into force on 01.01.2006. English version available at: https://www.riigiteataja.ee/en/eli/ee/Riigikogu/ act/504072016003/consolide (04.03.2017).

${ }^{44}$ Sub-section 232(1) of the Estonian Code of Civil Procedure.

45 Sub-section 232(2) of the Estonian Code of Civil Procedure. 
In Romania, the provision of Article 9(2) is going to be transposed almost literally, meaning that final decisions originating from other Member States may be filed as prima facie evidence.

In Slovakia, a final decision on a competition infringement issued in another Member State is considered prima facie evidence, unless proven otherwise. ${ }^{46}$ It is, however, reported that the wording of the relevant clauses is not clear enough, thus creating legal uncertainty. Based on the current wording, is it not clear what exactly is rebuttable - the piece of evidence (admissibility issue) or the facts provided in the relevant decision.

Slovenia has decided not to fully equate the final decisions of the Slovenian NCA and those of the NCAs of other Member States. Thus, final decisions deriving from other Member States are accepted, subject to a rebutted presumption. Interestingly also, damages actions are mostly stand-alone actions, a fact considered to be the result of the inefficiency of the Slovenian NCA, as well as the tight time limits regarding its statutes of limitations. It is also reported, however, that courts do stay their proceedings when the NCA initiates an investigation in the same matter. If the NCA decides that no infringement has taken place, the courts continue with a full assessment of the facts of the case. However, it seems that a decision on 'non-infringement' is used as evidence in favour of the defendant.

\section{Conclusion}

As provided in the previous section, most of the CEE countries ${ }^{47}$ under review have already implemented, or are in the process of implementing Article 9(1) of the Damages Directive into their national legislation. It can be assumed, therefore, that harmonisation is possible on a rather high level, and that the infringement decisions issued by domestic NCAs or relevant courts subject to Articles 101 and 102 TFEU or national competition law will, indeed, become irrefutable. ${ }^{48}$ The situation is, however, different with regard to Article 9(2) of the Damages Directive; the vision and understanding across the reviewed CEE countries differ significantly in this context. Most of the reviewed Member States granted final decisions on an infringement of competition law issued in another Member State some evidentiary significance. Bulgaria constitutes an exception here, which disregards the possibility to

\footnotetext{
46 As set out in Section 4(2) of Act 350/2016.

47 With the exeption of Bulgaria, where the binding effect of decisions issued by the domestic NCA requires confirmation by the Bulgarian Supreme Administrative Court.

48 Art. 9(1) of the Damages Directive.
} 
grant such final decisions evidentiary significance. It is, therefore, not clear if the decisions taken in other Member States could be presented as evidence in Bulgaria. Some Member States claim that their civil procedural rules are already in compliance with Article 9(2) and no harmonisation is needed, for example Estonia.

It seems, however, every Member State has its own approach when it comes to the relevant details and it may be that a decision of a NCA may be treated differently when presented in legal actions in multiple Member States. In some, it may well be accepted as prima facie evidence or even as preferred evidence. It is, however, not impossible that in other Member States it will be considered as a mere declaration of facts based on which the local judge provides its legal assessment.

Even though not perfect in every possible aspect, the Damages Directive is a big step forward towards enabling injured persons to claim damages sustained from competition law violators, as it is incentivising the victims to seek relief (Peyer, 2016). It prescribes rules, including those on the binding effect of NCAs' decisions that enable injured parties to consider the potential outcome of the case, including the expected costs and return. It is rather obvious that rules reducing potential legal costs of the claimant incentivise injured parties to take action. Also, an injured person is more likely to start legal actions if the probability of success is greater. Making evidence more easily available, and providing the irrefutability of evidence, results in cost efficiencies for the claimant (Peyer, 2016).

When we aim to increase legal certainty and reduce inconsistency in the application of Articles 101 and 102 TFEU throughout the EU, it is relevant to ensure that the findings of an infringement of Article 101 or 102 TFEU in a final decision issued by a NCA or a review court are not re-litigated in subsequent actions for damages, provided such findings cover only the nature of the infringement and its material, personal, temporal and territorial scope. A direct effect of this is an increase in the effectiveness and procedural efficiency of actions for damages. Indirectly, this will foster the functioning of the internal market for undertakings and consumers. What may, however, limit the use of the provided tool is the increasing use of commitment decisions, as argued by Dunne. Binding effect is granted to infringement decisions only, thus commitment decisions, which are meant to modify the behaviour of the involved companies, do not contain formal finding of a violation (Dunne, 2015).

In the US, private and governmental enforcement are considered complementary (Kaplan, 2001). Nevertheless, US private enforcement has lately been under critical review concerning whether the system is productive enough. Some US commentators held the system of private antitrust enforcement counterproductive, with its class action and triple damages concept (see for 
example Rosenberg and Sullivan, 2005). Other commentators disagreed and appraised the systems as it seems to be the only way to compensate the victims for their losses (Crane, 2010; Davis and Lande, 2013). Even the US triple damages principle is considered justified as a real deterrence to violators. Some commentators even stated that private enforcement does more than anti-cartel programmes of governmental agencies (Davis and Lande, 2013). Although the US system strongly promotes the complementary approach and the synergy of private and public enforcement (Kaplan, 2001), it is interesting to note that in the US, there are more independently initiated cases than follow-on claims; still, the overall number of follow-on cases seems to depend on the public enforcement activity (Kauper and Snyder, 1986).

The binding effect of final decisions issued by NCAs will certainly facilitate private antitrust litigations across the EU, thus it constitutes a big step forward. The follow-on rule provides legal certainty and most probably enables the injured parties to estimate the costs as well as the outcome of a potential case. There is, however, also the risk that it will limit claimants with regard to infringements that have not been investigated by NCAs at all or with respect to the scope thereof.

\section{Literature}

Blažo, O. (2017). Slovakia. In: Piszcz, A. (ed.), Implementation of the EU Damages Directive in Central and Eastern European Countries (247-262). Warsaw: Centre for Antitrust and Regulatory Studies.

Bodnár, P.M. (2017). Slovakia. In: Piszcz, A. (ed.), Implementation of the EU Damages Directive in Central and Eastern European Countries (127-156). Warsaw: Centre for Antitrust and Regulatory Studies.

Butorac Malnar, V. (2017). Croatia. In: A. Piszcz (ed.), Implementation of the EU Damages Directive in Central and Eastern European Countries (55-84). Warsaw: University of Warsaw, Faculty of Management Press.

Crane, D.A. (2010). Optimizing Private Antitrust Enforcement. Vanderbilt Law Review 63(3), 673-724. Retrieved from: http://repository.law.umich.edu/cgi/viewcontent.cgi?a rticle $=1129 \&$ context $=$ articles $(07.06 .2017)$.

Davis, J.P and Lande, R.H. (2013). Defying Conventional Wisdom: The Case for Private Antitrust Enforcement. Georgia Law Review 48(1), 1-82. Retrieved from: https:// poseidon01.ssrn.com/delivery.php?

ID $=7900860901271000940200701210981211170160830530100570281030750021261041050$ $78103015074010017029060104024054108107079108082008102005023049082020125096-$ 07808209811412706500706010108202606610709310412109000010600411901012008212 $0116104094076127124080031125 \& \mathrm{EXT}=$ pdf $(07.06 .2017)$.

Dunne, N. (2015). Courage and compromise: the Directive on Antitrust Damages (Legislative Comment). European Law Review 40(4), 581-597.

Foer, A.A. and Cuneo, J.W. (2012). The International Handbook on Private Enforcement of Competition Law. Cheltenham: Edward Elgar Publishing Limited. 
Grassani, S. and Ansaldo, P. (2013). The Binding Nature of NCA Decisions in Antitrust Followon Litigation: Is EU Antitrust Calling For Affirmative Action?. CPI Chronicle 2013(1). Retrieved from: https://www.competitionpolicyinternational.com/assets/ Uploads/GrassaniAug-131.pdf (07.06.2017).

Jerneva, J. and Druviete, I. (2017). Latvia. In: A. Piszcz (ed.), Implementation of the EU Damages Directive in Central and Eastern European Countries (157-178). Warsaw: University of Warsaw, Faculty of Management Press.

Kaplan, M.A. (2001). Antirust as a Public-Private Partnership: A Case Study of the NASDAQ Litigation, Case Western Reserve Law Review 52(1), 111-131. Retrieved from: http://scholarlycommons.law.case.edu/caselrev/vol52/iss1/8 (07.06.2017).Kauper, T.E and Snyder, E.A. (1986). An Inquiry into the Efficiency of Private Antitrust Enforcement: Follow-on and Independently Initiated Cases Compared. Georgetown Law Journal 74(4), 1163-1230.

Komninos, A. (2007). Effect of Commission decisions on private antitrust litigation: Setting the story straight. Common Market Law Review 44(5), 1387-1428.

MacGregor, A and Boyle, D. (2014). Private antitrust litigation in the EU: Levelling the playing field. Retrieved from: o http://www.mondaq.com/unitedstates/x/311890/ Antitrust + Competition/Private + Antitrust + Litigation $+\mathrm{In}+\mathrm{The}+\mathrm{EU}+$ Levelling $+\mathrm{Th}$ e+Playing + Field (07.06.2017).

Merola, M. and Armati, L. (2016). The Binding Effect of NCA Decisions under the Damages Directive: Rationale and Practical Implications. Italian Antitrust Review 3(1), 87-108. Retrieved from: http://iar.agcm.it/article/view/12024/11042 (07.06.2017).

Mikelènas, V. and Zaščiurinskaitè, R. (2017). Lithuania. In: A. Piszcz (ed.), Implementation of the EU Damages Directive in Central and Eastern European Countries (179-210). Warsaw: University of Warsaw, Faculty of Management Press.

Mircea, V. (2017). Romania. In: A. Piszcz (ed.), Implementation of the EU Damages Directive in Central and Eastern European Countries (237-246). Warsaw: University of Warsaw, Faculty of Management Press.

Nazzini, R (2015). The Effect of Decisions by Competition Authorities in the European Union. Italian Antitrust Review 2, 68-97, doi: 10.12870/iar-11577. Retrieved from: http:// iar.agcm.it/article/view/11577/10731 (07.06.2017).

Panzani, L (2015). Binding Effect of Decisions adopted by National Competition Authorities. Italian Antitrust Review 2, 98-102, doi: 10.12870/iar-11578. Retrieved from: http://iar.agcm.it/article/view/11578/10732 (07.06.2017).

Petr, M. (2017). Czech Republic. In: A. Piszcz (ed.), Implementation of the EU Damages Directive in Central and Eastern European Countries (85-108). Warsaw: University of Warsaw, Faculty of Management Press.

Petrov, A. (2017). Bulgaria. In: A. Piszcz (ed.), Implementation of the EU Damages Directive in Central and Eastern European Countries (25-54). Warsaw: University of Warsaw, Faculty of Management Press.

Pärn-Lee, E. (2017). Estonia. In: A. Piszcz (ed.), Implementation of the EU Damages Directive in Central and Eastern European Countries (109-126). Warsaw: University of Warsaw, Faculty of Management Press.

Peyer, S. (2016). Compensation and the Damages Directive. European Competition Journal, 12(1), 87-112.

Piszcz, A. (ed.). (2017). Implementation of the EU Damages Directive in Central and Eastern European Countries. Warsaw: University of Warsaw, Faculty of Management Press. 
Piszcz, A. and Wolski, D. (2017). Poland. In: A. Piszcz (ed.), Implementation of the EU Damages Directive in Central and Eastern European Countries (211-236). Warsaw: University of Warsaw, Faculty of Management Press.

Rosenberg, D. and Sullivan, J.P. (2005). Coordinating Private Class Action and Public Agency Enforcement of Antitrust Law. Harvard Law and Economics Discussion Paper No. 523. Retrieved from: https://ssrn.com/abstract=795524 (07.06.2017).

Segal, I.R. and Whinston, M. D. (2006). Public vs. Private Enforcement of Antitrust Law: A Survey. Stanford Law and Economics Olin Working Paper No. 335. Retrieved from: https://ssrn.com/abstract=952067 (07.06.2017).

Vlahek, A. and Podobnik, K. (2017). Slovenia. In: A. Piszcz (ed.), Implementation of the EU Damages Directive in Central and Eastern European Countries (263-298). Warsaw: University of Warsaw, Faculty of Management Press.

Wright, K. (2016). The Ambit of Judicial Competence after the EU Antitrust Damages Directive. Legal Issues of Economic Integration 43(1), 15-40. 